\title{
Exercise-induced hyperinsulinism
}

INSERM

\section{Source}

INSERM. (1999). Orphanet: an online rare disease and orphan drug data base. Exerciseinduced hyperinsulinism. ORPHA:165991

Exercise-induced hyperinsulinism (EIHI) is a form of diazoxide-sensitive diffuse hyperinsulinism ( $\mathrm{DHI}$ ) characterized by episodes of hypoglycemia induced by exercise due to an inappropriate lactate and pyruvate sensitivity in pancreatic beta-cells. 